\title{
Vegetation analysis, physico-chemical properties and economic potential of damar (Agathis dammara) in Mount Halimun Salak National Park,West Java, Indonesia
}

\author{
YELIN ADALINA", RENY SAWITRI" \\ Forest Research and Development Center. Jl. Gunung Batu No. 5, Bogor 16610, West Java, Indonesia. Tel. +62-251-8633234; 7520067. \\ Fax.: +62-251-8638111; ’email: yelinadalina@yahoo.com, "vemail: sawitri_reny@ yahoo.com
}

Manuscript received: 5 November 2019. Revision accepted: 19 February 2020.

\begin{abstract}
Adalina Y, Sawitri R. 2020. Vegetation analysis, physico-chemical properties and economic potential of damar (Agathis dammara) in Mount Halimun Salak National Park, West Java, Indonesia. Biodiversitas 21: 1122-1129. Analysing the potential of nontimber forest product (NTFP) plants in Mount Halimun Salak National Park (MHSNP) is one of the important aspects in supporting conservation and improving the economic status of communities around the forest. This study aims to determine the economic potential and benefits of damar plants (Agathis dammara) in MHSNP area of Kawah Ratu Resort, Sukabumi District, West Java, Indonesia along with analysis of damar plant forest and physico-chemical analysis of the copal/resin. The selection of research village was by purposive sampling and the selection of respondents was by random sampling. Forest vegetation in the Kawah Ratu Resort is entirely dominated by damar plants. The Important Value Index (IVI) of damar plant trees is $300 \%$ and the density is 582 trees/ha. The quality of copal from Kawah Ratu Resort meets SNI standards in parameters like ash content, soft point and melting point, while the saponification number is above SNI standard. Level of dung in copal chunks meet SNI standards and has better quality than copal in the form of powder. The present average income of farmers from resin tapping is Rp 624,000/person /month, which makes an average contribution of $63.08 \%$ to the total household income of farmers. But the actual economic potential of gum resin in Kawah Ratu Resort was estimated to be around Rp 596,920,000/month.
\end{abstract}

Key words: Economic value, gum resin, Kawah Ratu Resort, Mount Halimun Salak National Park

\section{INTRODUCTION}

Damar (Agathis dammara) is an important type of local plant, although its growth is slow. These plants provide benefits to resist erosion and protect water sources (store them) through strong roots (Haryadi et al. 2019). Damar plants found in the Mount Halimun Salak National Park (MHSNP) area was originally a production forest managed by Perum Perhutani. In the year 2003, Mount HalimunNational Park (MHNP) area was expanded from 40,000113,357 ha in accordance with the decree issued by the Indonesia's Ministry of Forestry Number 175/Kpts-II/2003 as one entity called Mount Halimun-Salak National Park (MHSNP) (Adalina et al. 2014).

MHSNP expansion that includes residential areas, agricultural land, and areas for other economic activities. National parks in Indonesia are designed for nonexploitative use. Despite economic benefits which can be obtained, there is a balance between efforts for conservation and for improving the living conditions of surrounding communities (Ekayani et al. 2019). It is hoped that the national parks will contribute to the welfare of the surrounding community, while the integrity and preservation of natural resources in the national park area is ensured (Mukul et al. 2010).

Social conflicts related to the low economy of the communities around the area, land ownership, intensive land use, and ongoing timber exploitation by the rural community are major problems for the management of this national park (Rosleine et al. 2014). Communities are part of the forest ecosystem and so they will maintain the sustainability of forests if provided with some benefits, both direct and indirect, from forest resources (Hutauruk et al. 2018). In general, communities around the forest directly utilize forest resources. There are 314 subvillages (or settlements) located within the national park area, and around 100,000 people rely on the natural resources in the park for their daily livelihoods. According to the legal framework, unless the areas are otherwise designated as a special zone, productive land use and resource harvest are illegal and subject to a fine and penalty (Kubo and Supriyanto 2010). Non-timber forest products (NTFPs) are one of the forest resources that can have an impact on increasing the income of people around the forest (Melese 2016), but have not been managed and utilized optimally. The benefits of NTFPs can increase the income of local people and contribute towards reducing poverty which may be beneficial for the conservation of forest resources (Ahenkan and Boon 2011; Negi et al. 2011).

The local community realized that the forest area must exist to support their life. Although not the entire local community gets a direct benefit from the forest by collecting forest products (Nakagoshi et al. 2014). Community involvement in maintaining the preservation of the MHSNP area needs to be pursued, among others, 
through the utilization of non-timber forest products (NTFPs), including a collection of damar resin. However, if livelihood activities are not linked to conservation, it would strengthen heteronomous motivation because the commitment to conservation by local people is instrumental in an economic incentive (Desmiwati and Christian 2019). Forest management needs to be focused on the production of NTFPs which can generate income for local communities by taking into account ecological factors (Ahenkan and Boon 2011). The utilization of resin as an NTFP in the MHSNP area is an alternative that can accommodate the economic interests of communities around the forest. This situation happened in surrounding protected areas in India that harvested gum resin from Boswellia serrata Roxb for sale and cultural activation (Soumyu et al. 2019). Therefore, the benefits and economic values of dammar plants in the MHSNP area needs to be analyzed, so that the benefits can be understood by all stakeholders in managing MHSNP. This study, therefore, aims to determine the potential, quality, and use of damar resin plants by the community at the Kawah Ratu Resort, Mount Halimun Salak National Park.

\section{MATERIALS AND METHODS}

\section{General conditions of study area}

The study was conducted in September-November 2017 at the Cangkuang Block of Kawah Ratu Resort, Mount Halimun Salak National Park, West Java Province, Indonesia. Administratively, the research location for vegetation analysis belongs to Cidahu Village, Cidahu Sub-district, Sukabumi District, West Java Province, Indonesia. While, tapping of damar sap was conducted in Cidahu Village (Cidahu Sub-district), Tenjolaya Village (Cicurug Subdistrict), and Parakan Salak Village (Parakan Salak Subdistrict) of Sukabumi District, West Java Province, Indonesia (Figure 1).

The damar plant area in Cangkuang Block is 27 hectares which age about 25-27 years (Adalina 2015). This area is included in the Kawah Ratu Resort, Section III of Sukabumi, Gunung Halimun Salak National Park Office. $6,394.23$ ha. Geographically, the study area is located at $106^{\circ} 43^{\prime} 10,6$ " $\mathrm{E}$ and $06^{\circ} 45^{\prime} 10,8^{\prime \prime} \mathrm{S}$. The altitude villages ranges 600-1,699 meters above sea level, the temperature of $24^{\circ} \mathrm{C}$ and the humidity of $75 \%$. According to Schmidt and Ferguson (1951), it is included in rainfall type A, with an average rainfall of 4000-6000 mm per year. The areas are wavy, hilly and mountainous topography. The slope is in the range of $15-40 \%$. Soil types are regosol brown, andosol, podsolik reddish brown.

\section{Vegetation analysis}

This research used a quantitative methodology with the support of a qualitative approach. The research methods used were survey, observations, and interviews using a questionnaire. The selection of research villages was purposively based on the use of damar plants in the form of tapping resin by the community around the forest. The selection of 22 respondents was made randomly, based on respondents who use damar plants at Kawah Ratu Resort for collecting resin. In addition to the respondents, in-depth interviews were also conducted with other stakeholders involved in the management of MHSNP, including community leaders, NGOs, village heads and MHSNP staff.
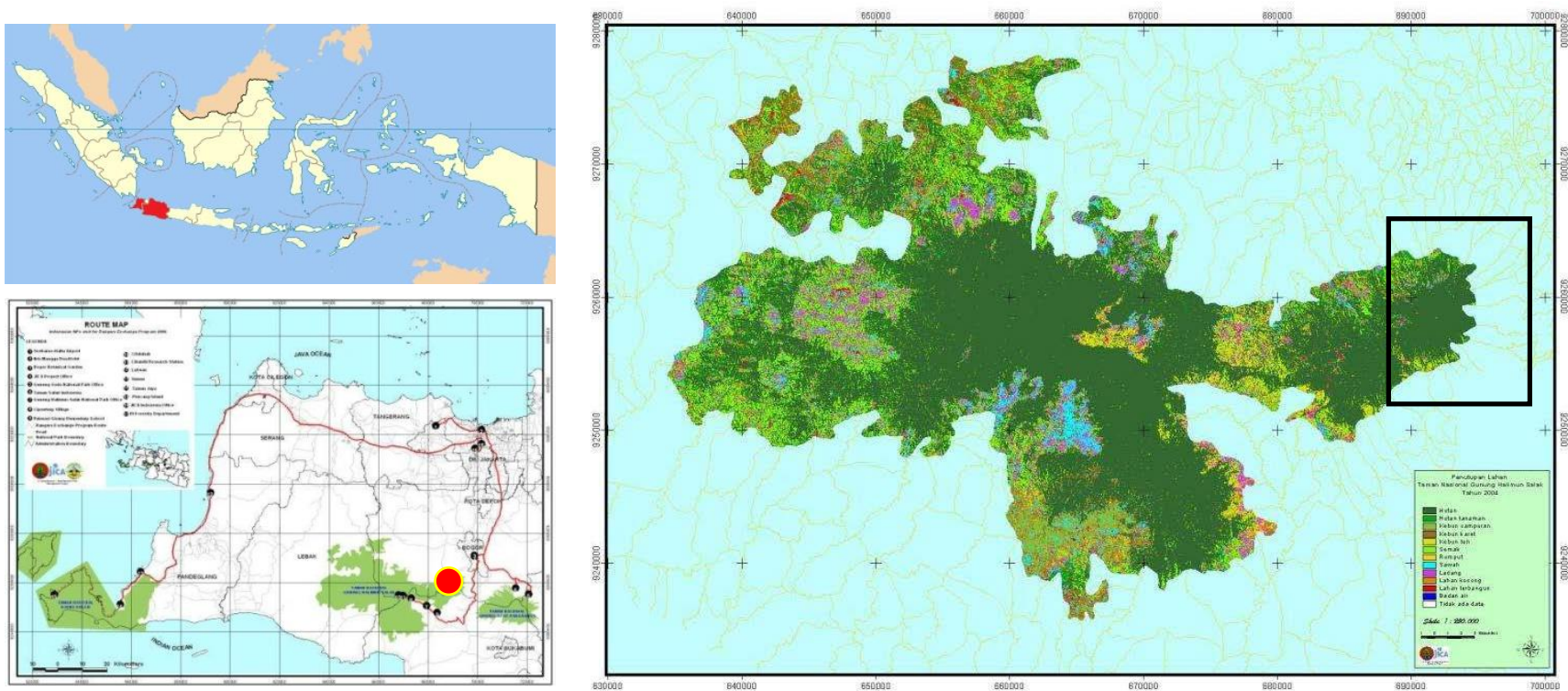

Figure 1. Study area in Kawah Ratu Resort, Mount Halimun Salak National Park, Sukabumi District, West Java Province, Indonesia 
Vegetation analysis was carried out at the Cangkuang Block of Kawah Ratu Resort, through measurement of tree height and diameter of for different growth stages. Vegetation measurements were made in 10 circular plots, each with a radius of $17.8 \mathrm{~m}$, and with an area of 0.1 ha. The area of vegetation measurement was 1.0 ha or $3.7 \%$ of the total damar area in the Cangkuang Block. In each plot, a circle is made of four quadrants in the North-East, EastSouth, South-West, West-North directions. The data that has been collected is analyzed to determine individual density, frequency of species and dominance. Based on these three parameters important value is calculated that can be used as a basis for knowing the dominant types.

\section{Damar resin analysis}

To find out the quality of copal produced by the species of Agathis dammara tree, physicochemical properties of copal with reference to the Indonesian National Standard (SNI) 7634-2011, was conducted (BSN 2011). The parameters analyzed consisted of ash content, soft point, melting point, acid number, saponification number and dirt content. Material for the analysis of damar/gum resin (copal) was obtained from copal collectors in Cidahu Village, Cidahu Sub-district, Sukabumi District. Copal is traded in chunks and in the form of powder. A total of 2 copal samples in the form of chunks and powder, $0.5 \mathrm{~kg}$ each, were obtained from copal collectors in Cidahu Village. Copal quality analysis was carried out at the Forest Products Research and Development Center Laboratory, Bogor, Indonesia.

Economic benefits of NTFP from damar plants is evaluated through the direct use value, which is the NTFP (copal) utilized directly by the communities around the MHSNP area. The valuation is based on market price approach.

\section{Data analysis}

Vegetation data were analyzed to determine the Importance Value Index (IVI) based on species density, dominance, and frequency based on the formula given by Soerianegara and Indrawan (2002).

$\operatorname{Density}(\mathrm{K})=\frac{\Sigma \text { individu }}{\text { sample plot area }}$

Relative density

$(\mathrm{KR})=\frac{\text { absolute density of each type } \mathrm{x} 100 \%}{\text { total absolute density of all types }}$

Dominance $(\mathrm{D})=\frac{\Sigma \text { basic area }}{\text { sample plot area }}$

Relative dominance

$(\mathrm{DR})=\frac{\text { absolute dominance of each type } \mathrm{x} 100 \%}{\text { total absolute dominance }}$

Frequency $(\mathrm{F})=\frac{\Sigma \text { sampling point of one sample }}{\Sigma \text { sample plot area }}$
Relative frequency

$(\mathrm{FR})=\frac{\text { absolute dominance of each type } \mathrm{x} 100 \%}{\text { total absolute frequency }}$

Important value index (IVI) for pole and tree-level

$\mathbf{I V I}=(\mathbf{K R})+(\mathbf{D R})+(\mathbf{F R})$

Important value index (IVI) for seedlings and saplings

$\mathbf{I V I}=(\mathbf{K R})+(\mathbf{F R})$

Economic value of Copal was calculated by calculating the average copal harvest ( $\mathrm{kg} / \mathrm{respondent/year)} \mathrm{and} \mathrm{the}$ economic value of copal ( $\mathrm{Rp} / \mathrm{year} / \mathrm{ha})$ with the formula:

$$
\begin{aligned}
\mathrm{XPGD} & =\frac{\mathrm{TGD}}{\Sigma \mathrm{RT}} \\
\mathrm{NEGD} & =\mathrm{XPGD} \times \mathrm{HGD}
\end{aligned}
$$

Where:

XPGD : Average copal retrieval (kg/respondent/year)

TGD : Total copal retrieval (kg/year)

NEGD : Copal economic value (Rp/ha/year)

HGD : Copal price $(\mathrm{Rp} / \mathrm{kg})$

\section{RESULTS AND DISCUSSION}

\section{Analysis of damar vegetation}

The Importance Value Index (IVI) shows that there is only one type of tree-level in the damar forest in the MHSNP area at Kawah Ratu Resort, namely damar plant (Agathis dammara) with a $300 \%$ IVI, species density of 582 individuals/ha and a relative density of $100 \%$. Likewise at the mast level dominated by damar plants with IVI $300 \%$, species density of 27 individuals/ha, and relative density of $100 \%$. The sapling level plants were not found (Table 3). This shows that the condition of vegetation in the study site is a monoculture plantation that is dominated by one type of plant. The high IVI level of the Agathis dammara tree at the study site shows the magnitude of the species dominance at the site of growth. One factor that may have caused the high IVI value, which indicated the dominance of these species, was that they were represented by more individuals than the other species. Because species diversity is composed of species evenness and richness (Wiharto and Mochtar 2012). The results of IVI at Ratu Crater Resort are different when compared to the damar forest in Cipeuteuy Village, Kabandungan Subdistrict, Gunung Kendeng Resort namely there are 2 types of plants at the tree level consisting of resin plants with an IVI value of $276.2 \%$ and chempedak plants (Artocarpus champedan) with an IVI of $23.9 \%$. There are 2 types at pole levels, namely Agathis damara with IVI $272.8 \%$ and Coffea spp with IVI $27.2 \%$. Adalina et al. (2014) reported that the presence of chempedak and coffee plants in the damar forest in Cipeuteuy Village was caused by civet animals (Paradoxurus hermaphroditus) which eat and spread coffee beans. This area was highly suitable until moderately suitable as habitat civet (Chairani et al. 2017) 
Table 3. Important Value Index of vegetation types in Agathis dammara forests in the Kawah Ratu Resort, MHSNP, Indonesia

\begin{tabular}{lcccrrr}
\hline & Type of plant & K (individu/ha) & KR $(\boldsymbol{\%})$ & DR (\%) & FR (\%) & IVI (\%) \\
\hline Tree level & Damar & 582 & 100.0 & 100.0 & 100.0 & 300 \\
Pole level & Damar & 27 & 100.0 & 100.0 & 100.0 & 300 \\
Stake level & - & - & - & & - & - \\
\hline
\end{tabular}

Note: KR: relative density ; DR: relative dominance; FR: relative frequency; IVI: important value index

Table 4. The average height and diameter of the damar plants (Agathis dammara) in the Kawah Ratu Resort, MHSNP, West Java, Indonesia

\begin{tabular}{clccc}
\hline $\begin{array}{c}\text { Plot } \\
\text { no. }\end{array}$ & \multicolumn{1}{c}{ Coordinates } & $\begin{array}{c}\text { Mean } \\
\text { TBC } \\
(\mathbf{m})\end{array}$ & $\begin{array}{c}\text { Mean } \\
\mathbf{T T} \\
(\mathbf{m})\end{array}$ & $\begin{array}{c}\text { Mean D } \\
(\mathbf{c m})\end{array}$ \\
\hline 1 & $999 / 0690078 / 9253176$ & 3.32 & 23.16 & 108.63 \\
2 & $10008 / 0690025 / 9253211$ & 3.09 & 21.14 & 111.86 \\
3 & $1025 / 0690019 / 9253293$ & 3.66 & 19.24 & 105.58 \\
4 & $1025 / 0690019 / 9253293$ & 3.28 & 20.09 & 112.49 \\
5 & $1008 / 0690073 / 9253229$ & 3.90 & 22.75 & 117.83 \\
6 & $990 / 0690099 / 9253227$ & 4.95 & 26.73 & 107.66 \\
7 & $996 / 0690129 / 9253220$ & 4.41 & 28.40 & 114.24 \\
8 & $998 / 0690168 / 9253190$ & 3.85 & 25.86 & 109.5 \\
9 & $976 / 0690206 / 9253171$ & 4.04 & 27.45 & 122.57 \\
10 & $969 / 0690240 / 9253148$ & 5.22 & 27.61 & 115.13 \\
\hline \multicolumn{4}{c}{ Note: TBC: Branch-free height; TT: Total height; D: Diameter }
\end{tabular}

Table 5. Damar resin quality analysis results

\begin{tabular}{lccc}
\hline \multirow{2}{*}{ Parameters } & \multicolumn{2}{c}{ Sample code } & Copal based \\
\cline { 2 - 3 } & $\begin{array}{c}\text { Sample 1 } \\
\text { (powder } \\
\text { copal) }\end{array}$ & $\begin{array}{c}\text { Sample 2 } \\
\text { (chunk } \\
\text { copal) }\end{array}$ & $\begin{array}{c}\text { quality } \\
\text { classification } \\
\text { SNI 7634-2011 }\end{array}$ \\
\hline Ash content $(\%)$ & 0.80 & 0.13 & $0.3-5$ \\
Soft point $\left({ }^{\circ} \mathrm{C}\right)$ & 117.3 & 106.0 & $90-130$ \\
Melting point $\left({ }^{\circ} \mathrm{C}\right)$ & 123 & 118 & $90-130$ \\
Acid number $(\%)$ & 145.66 & 155.92 & $125-150$ \\
Lathering number $(\%)$ & 208.7 & 285.28 & $140-170$ \\
Impurities $(\%)$ & 7.73 & 4.30 & $3-5$ \\
\hline
\end{tabular}

Density of damar plant at tree level is 582 individuals/ha. The results of this analysis are different when compared to the level of damar plant tree density in Cipeuteuy Village, Gunung Kendeng Resort, which is 452 individual/ha (Adalina et al. 2014). This shows that the damar forest in both locations has a high density of trees which affected to diameter of tree. Normal tree density in production forests is 250 trees/ha (Lestari et al. 2019).

Adalina (2015) reported that there are 99 species of plants that live naturally, under the stand of resin in the Kawah Ratu Resort and as many as 39 species are medicinal plants. Rane plant (Selaginella uncinata) is an understorey with the highest IVI value of $35.93 \%$ with a density of 18,250 individuals/ha. In general, communities around the forest often use various types of medicinal plants found in the MHSNP area as traditional medicines (Setyawan 2009). Medicinal plant species that grow in the
MHSNP area can be developed in buffer areas as a source of community income (Adalina 2015). The undergrowth is one of the important components in the forest ecosystem that must be taken into account (Asmayannur and Syam 2012).

In Table 4, it can be seen that the tree height of Agathis dammara up to branch level in Cidahu Village, Kawah Ratu Resort ranges from 3.09 to 5.22 meters with an average of $3.97 \mathrm{~m}$. The total height of resin plants ranges from $19.24 \mathrm{~m}$ to $28.40 \mathrm{~m}$ with an average of $24.24 \mathrm{~m}$. The diameter of resin plants ranges from 105.58 to $122.57 \mathrm{~cm}$ with an average of $112.55 \mathrm{~cm}$. The height and diameter of the damar plant at this location are greater when compared to the damar forest in Cipeuteuy Village, Mount Kendeng Resort, where average tree height was $20.29 \mathrm{~m}$ and average diameter was $27.21 \mathrm{~m}$ (Adalina et al. 2014 ). This is due to differences in environmental conditions such as temperature, rainfall, soil type, altitude and age. Based on research of Agathis dammara in Balikpapan, East Kalimantan, intersection point between Mean Annual Increament (MAI) and Current Annual Increament (CAI) resulted the optimum production at age of 25 years (Setiawan et al. 2019) (Figure 2).

\section{Copal quality}

The results of the analysis of the physico-chemical properties of copal are listed in Table 5. The ash content of the copal powder was higher than the copal in the form of chunks. This shows that copal powder contains more impurities than copal chunks, but both samples have ash content values that meet the standards required by the Indonesian National Standard (SNI) 7634-2011 which is $0.3-5 \%$. When compared with the copal value of the East Banyumas KPH (Lukmandaru 2017), the ash content in this study was higher. High ash content indicates the number of impurities contained and will have an impact on quality. To improve the quality of copal, it is necessary to reduce levels of impurities through sorting which should be better and more thorough (Gigliarelli et al. 2015).

Softening points of damar copal were observed in the range of 100-120. Tg and softening point values indicate soft nature, while the sharp melting point indicates the absence of the amorphous nature of the copal (Fathi et al. 2016). The results of the analysis showed that both copal samples have soft points that meet SNI requirements. Powdered copal soft spots are higher than chunk copal. The results of this study indicate that chunks of copal contain fewer impurities and produce lower soft spots than powder. 


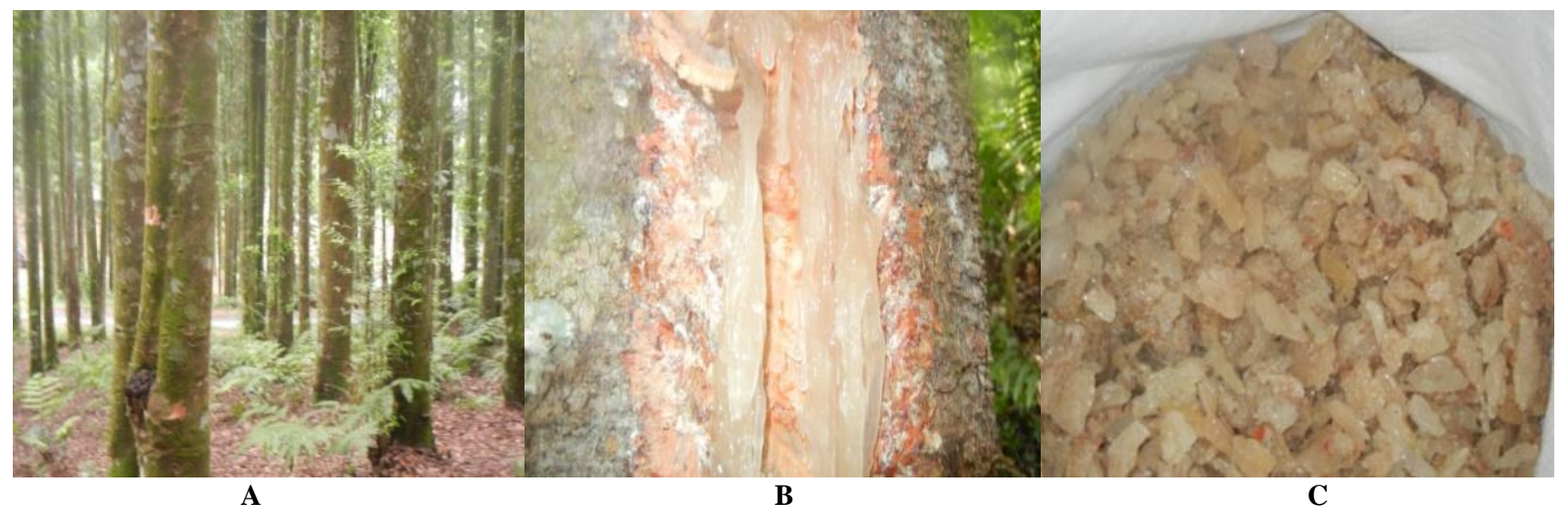

Figure 2.A. Damar forest at Kawah Ratu Resort, B. A tapped damar tree, C. Copal leads

The results of the melting point analysis of the two copal samples are in the range of SNI standards. The larger the mass of dammar resin, the shorter the ignition delay, this is because the mass of the dammar resin, the large amount of gas formed from the heating results more and more so that a certain amount of gas is burned (Jamal 2019). Acid numbers of chunks is above SNI standards, whereas 1 acid numbers of powder meets SNI standards. This indicates that chunk copal has a high acid content. The higher the acid number, the higher the soft point (Morhlade et al. 2006). The results of this study are not so where the chunk copal acid number is higher than the powdered copal but it was not showing higher soft points.

Saponification is the total amount of fatty acids contained in copal. The results of the analysis of two copal samples indicate that they have saponification numbers above the SNI standard. This may be because of differences in soil biophysical conditions. The dirt content of chunks was within SNI standards, whereas that of powder was above SNI standards. This is in line with the results of this study that the levels of impurities in powder was higher than in chunks with higher ash content as well. Dirt contained in copal was sand, soil and tree bark. This shows that copal powder contains organic and inorganic ingredients which are insoluble in toluene. To reduce levels of insoluble substances in toluene through purification treatment with heating. When compared with Kopal from KPH Banyumas Timur (Lukmandaru 2017), the levels of impurities and acid numbers of samples used in this study are lower. This indicates variations in chemical properties that are influenced by geographical factors.

\section{Economic valuation of benefits of damar plants}

The forests of damar plants in the MHSNP area were originally a production forests managed by Perum Perhutani. Prior to the expansion of the area, community involvement in tapping damar resin was evident during the management of Perum Perhutani through Community Forest Management (PHBM). Communities are aware of their dependence on forest resources and the vital need to conserve them. Reviewing some research conducted on resin sap collection has proven that resin damar can conserve forest resources including biodiversity and provide economic benefits to the community (Lee et al. 2015). To increase the income of communities around forests that have a dependency on forest resources, forest management needs to be planned around the development of NTFPs, taking into account socioeconomic factors and forest conditions (Jacobson and Shiba 2012).

The management of MHSNP has made various efforts in optimizing the function of the forest by utilizing the existing potential of NTFP collection program and utilizing networking with various parties. The synergy of collaboration with communities around the forest is expected to support efforts to achieve MHSNP development goals. In line with the management efforts set forth in the 2007-2026 RPTN where multi-stakeholder partnerships are a social force to sustain the management of MHSNP. Therefore, we need a strategy that is able to accommodate the interests of the community through a socioeconomic approach that leads to improving the welfare of the community around the national park area. The economic development and biodiversity conservation can have complimentary goals, in order to meet the needs of communities (Nana and Techamadu 2014). Collection of NTFPs in conservation areas as a form of implementation of Government Regulation (PP) No 28 of 2011 concerning the management of Nature Reserves and Nature Conservation Areas. Article 35 states that "National parks can be utilized for traditional uses by local communities in the form of a collection of non-timber forest products".

The resin sap collection program (Agathis dammara) in the MHSNP area began to be community oriented in June 2012. The program actually began in September 2012 based on the MoU (Memorandum of Understanding) between the community/resin tapping farmers, MHSNP in collaboration with YPPS (Yayasan Observer Sukabumi Development) as a funder and container for the results of sap leads (Adalina et al. 2014). Damar resin collection at the Kawah Ratu Resort is undertaken in groups, with a total of eight groups consisting of 25 people tapping in the study area. This involves 3 groups each in Cidahu and Tenjolaya Villages, and 2 groups in Parakan Salak Village (Table 5). 
The area of damar plant managed by each group varies. The number of trees managed by each group ranges from 1,100 to 2,621 trees, with an average of 1,766 trees per group. The number of trees tapped by each tapping farmer varied, which ranged from 366-873 trees/person with an average of 560 trees/person. This depends on the tapping ability of farmers and the location of tapping. In general, the location of tapping means the distance of the residence of the tappers to the damar forest.

Damar plant area at the Kawah Ratu Resort is 288 hectares, and damar plant area that has been tapped is about 100 ha with a total of 14,134 trees. The number of resin trees that have been tapped is only about $35 \%$ of the total trees in the MHSNP Kawah Ratu Resort area. This is because of the lack of manpower for tapping.

The average number of tapped trees is 141 per hectare and the age of plants that are worth tapping is more than 15 years. The damar resin sap obtained at the Kawah Ratu Resort averaged 2,900 kg/month. The number of trees tapped ranged from 30 to 400 trees/person/day with an average of 151 trees/day/person. The average sap production of 150 trees is $26 \mathrm{~kg} /$ one harvest/week or 173 grams/tree/week equivalent to 693 grams/tree/month. In general, they do the tapping for 4-5 hours, ie from 8 am to 13 noon. The location of tapping from home ranges from $0.5 \mathrm{~km}$ to $5 \mathrm{~km}$ with an average of $2 \mathrm{~km}$. In the summer, from August to October, the average production is greater, while in the rainy season the production of sap decreases due to the growth of young leaves.

Amount of damar resin obtained from eight groups in 2012, 2013 and 2014 was $17,895 \mathrm{~kg}$ with an average of $2,982 \mathrm{~kg} / \mathrm{month}, 21,135 \mathrm{~kg}$ with an average of 1,761 $\mathrm{g} / \mathrm{month}$, and $20,078 \mathrm{~kg}$ with an average of 2,868 $\mathrm{kg} / \mathrm{month}$, respectively. The average income of resin collected by eight groups in 2012, 2013 and 2014, respectively, was Rp 8,947,000/month, Rp 6,700,000/month, and Rp $13,743,000 /$ month. The results of damar resin tapping obtained from each tapper varied, which ranged from 30$313 \mathrm{~kg} / \mathrm{month} /$ person with an average of 130 $\mathrm{kg} / \mathrm{month} /$ person. This depends on the number of trees tapped by each farmer, the farmers' skills in tapping, and the frequency of farmers tapping. Most farmers do not tap every day.

Problems encountered in collecting damar/gum resin at Kawah Ratu Resort includes mainly the lack of tapping staff. The selection of tappers is very limited, those who have experience when managing Perum Perhutani, and many of them are Yayasan Pemerhati Pembangunan Sukabumi (YPPS) members who have received training in tapping damar resin. There is a concern that resin plants will be damaged if there are too many tappers and if tapping is done by people who lack expertise. Another problem was the price of gum resin. The price received by tappers in 2012 was Rp 3,000/kg, since February 2013 it was Rp 3,500/kg, and in April 2013 it was Rp 4,000/kg, and prices increased to $\mathrm{Rp} 4,500 / \mathrm{kg}$ since April 2014. These price received by farmers was very low. Farmers want the price of resin to be adjusted with the standard price of resin in the market. Based on the Minister of Trade Regulation No. 22 of 2012, the benchmark price for copal gum resin is $\mathrm{Rp} 8,500 / \mathrm{kg}$ and the price is currently increasing to $\mathrm{Rp} 20,000$ per $\mathrm{kg}$ to $\mathrm{Rp} 22,000$ per $\mathrm{kg}$.

The low acceptance of farmers from the results of sap tapping, prevents tappers from tapping every day, so the production of sap is reduced. Sometimes, they do tapping only two weeks a month. YPPS sells the damar resin to a foreign company located in Cidahu for $\mathrm{Rp} 12,000 / \mathrm{kg}$ of sap.

Damar trees provide regular cash income from the harvesting and sale of damar resin. Fruit trees comprise almost a quarter of the tree community, although not in monthly basis, also provide additional cash income. According to Suminar (2013), per hectare of mature damar agroforest provides annual farm income ranging between Rp 1.65 million (no fruiting season) or US \$165, and Rp 3.84 million (in fruiting season) or US \$ 384. The contribution of damar resin income to the total income of tapper farmers in Kawah Ratu Resort is $14.29 \%$ to $100.0 \%$ with an average of $63.08 \%$ (Table 6). Farmer's income from the resin sap is supporting the household economy, to the extent of Rp150,000-1,409,000/person/month with an average of $\mathrm{Rp} 624,000 /$ person/month. This is different from the results of a study by Maryudi (2012) which states that the average income of resin tapping farmers in forest managed by Perum Perhutani is Rp1,000,000/month/ person. The average income of farmers from the results of resin sap at the Kawah Ratu Resort is lower than the results of this study. This is because some farmers lack understanding of tapping techniques, less number of tapping holes/trees, and a large number of resin trees that do not produce sap. Murugesan et al. (2011) suggested that An improved tapping technique using "Mitchie Golledge" knife coupled with ethephon (2 chloroethyl phosphonic acid) application can enhance production by about 22 times over that obtained from control and rapid wound healing A simple and safe technique of tapping with substantial increase in the yield of gum/gum resin is required to be developed for conservation of the fast depleting gum yielding forestry species.

Table 6. Farmers' Production and Income from resin sap yield at the Kawah Ratu Resort, Sukabumi

\begin{tabular}{lr} 
Parameter & Score \\
\hline Plant area at Kawah Ratu Resort (ha) & 296 \\
Number of trees/ha & 582 \\
Plant age (year) & 27 \\
Number of eavesdroppers (people) & 25 \\
Price of sap (Rp/kg) & 5,000 \\
$\begin{array}{l}\text { Distance to the location of tapping (km) } \\
\text { Number of plants managed/person }\end{array}$ & 2 \\
Number of trees tapped/day/person & 560 \\
Sap/tree/month production (gram) & 151 \\
Production of latex (kg)/mo/org) & 693 \\
$\begin{array}{l}\text { SAP income (Rp 1,000/month/org) } \\
\text { Average total farmer income from main and side } \\
\text { jobs (Rp/month/farmer) }\end{array}$ & 130 \\
Contribution of income from sap tapping to total & 624,000 \\
household income (\%) & 63.000 \\
\hline
\end{tabular}


Table 7. Location of tapping of resin plants and the number of trees being tapped

\begin{tabular}{|c|c|c|c|c|c|c|}
\hline Sub-district & Village & Group & $\begin{array}{c}\text { Number of people } \\
\text { per group }\end{array}$ & $\begin{array}{c}\text { Location of } \\
\text { tapping / blocks }\end{array}$ & Area (ha) & $\begin{array}{c}\text { Number of trees } \\
\text { tapped }\end{array}$ \\
\hline \multirow{5}{*}{ Cicurug } & Tenjolaya & 1 & 3 & Dono & 16 & 1,200 \\
\hline & & 2 & 3 & Kadal Menteng & 27 & 1,300 \\
\hline & & & & Cisuren & 27 & 1,321 \\
\hline & & 3 & 3 & Garuda & 28 & 1,200 \\
\hline & & & & Murbay & 21 & 1,300 \\
\hline \multirow[t]{3}{*}{ Cidahu } & Cidahu & 1 & 3 & Cangkuang & 27 & 1,200 \\
\hline & & 2 & 3 & Tanah Bereum & 16 & 1,300 \\
\hline & & 3 & 3 & Cukang Batu & 27 & 1,100 \\
\hline \multirow[t]{4}{*}{ Parakan Salak } & Parakan Salak & 1 & 4 & Parigi & 27 & 1,205 \\
\hline & & & & Kunenong & 24 & 1,200 \\
\hline & & 2 & 3 & Pasir Jambu & 27 & 1,008 \\
\hline & & & & Nalindung & 21 & 800 \\
\hline
\end{tabular}

The results of the vegetation analysis showed that the density of resin plants at the tree level was 582 trees/ha, with an average production potential of 693 grams /tree/month. Accordingly, damar resin production should be $403,326 \mathrm{~kg}$ damar $\mathrm{resin} / \mathrm{ha} / \mathrm{month}$. The area of the damar plant in Kawah Ratu Resort is 296 ha and resin production in Kawah Ratu Resort should be 119,384 $\mathrm{kg} / \mathrm{month}$. If the price is considered at Rp $5,000 / \mathrm{kg}$ of gum resin (copal), then it may be assumed that the economic potential of resin production at Kawah Ratu Resort is Rp 596,920,000/month.

In conclusion, forest vegetation in the Kawah Ratu Resort is entirely dominated by damar plants. The condition of the damar forest in this area is still good with a high level of tree density. The quality of copal from Kawah Ratu Resort, Sukabumi District meets SNI standards in parameters like ash content, soft point and melting point, while the saponification number is above SNI standard. Level of dung in copal chunks meet SNI standards and has better quality than copal in the form of powder.

Damar plants in MHSNP, Kawah Ratu Resort, besides having benefits on ecological aspects, also has considerable economic and socio-cultural benefits. From the economic aspect, it is one major source of income that can improve the economy of people around the forest. Damar/Gum resin (copal) contributes $63.08 \%$ of total income of tapping farmer households. The estimated economic potential of damar/gum resin (copal) at the Kawah Ratu Resort is around $\operatorname{Rp} 596,920,000 /$ month.

\section{ACKNOWLEDGEMENTS}

The authors thank the management of the Forest Research and Development Center, Bogor, Indonesia for funding and facilitating the implementation of the research work, and also all those who have helped in the implementation of this research.

\section{REFERENCES}

Adalina Y, Nurrochmat DR, Darusman D, Sundawati L. 2014. Harvesting of non timber forest product by the local communities in Mount Halimun-Salak National Park, West Java, Indonesia. Jurnal Manajemen Hutan Tropika 20 (2): 103-111.

Adalina Y. 2015. Keragaman jenis tumbuhan bawah berkhasiat obat di kawasan Gunung Salak, Jawa Barat. Prosiding Seminar Nasional Sewindu BPTHHBK Mataram. Pengarusutamaan Hasil Litbang Lingkungan Hidup dan Kehutanan Sebagai Lokomotif Pembangunan Berkelanjutan. Mataram, 1 Oktober 2015. [Indonesian]

Ahenkan A, Boon E. 2011. Non-Timber Forest Product (NTFPs): Clearing the confusion in semantics. J Hum Ecol 33 (1): 1-9.

Asmayannur I, Chairul, Syam Z. 2012. The analysis of understory vegetation on Jati Emas (Tectona grandis L.) and Jati Putih (Gmelina arborea Roxb.) stand in Andalas University Campus. Jurnal Biologi Universitas Andalas 1 (2): 173-178. [Indonesian]

BSN [Badan Standarisasi Nasional]. 2011. Kopal: SNI 7634: 2011. Badan Standarisasi Nasional, Jakarta. [Indonesian]

Chairani E, Supriatna J, Koestoer R, Moeliono m. 2017. Physical land suitability for civet arabca coffe: case study of Bandung and West bandung, Regencies, Indonesia. The 5th Geoinformation Science Symposium: IOP Conf Ser Earth Environ Sci 98: 012029. DOI: 10.1088/1755-1315/98/1/012029.

Desmiwati, Christian FY. 2019. Levelling up the collaborative forest management in Indonesia: a review. IOP Conf Ser Earth Environ Sci 285: 012008. DOI: 10.1088/1755-1315/285/1/012008

Ekayani M, Nuva, Pramudita D, Istiqomah A, Tampubolon BI, Osmaleli. 2019. Economic benefits of natural tourism: driving community's participation for conservation in Halimun Salak National Park, Indonesia. IOP Conf Ser Earth Environ Sci 285: 012003. DOI: 10.1088/1755-1315/285/1/012003

Fathi M, Mohebbi M, Koocheki A. (2016). Some physico-chemical properties of Prunus armeniaca L. gum exudates. Intl J Biol Macromol 82: 744-750.

Gigliarelli G, Becerra JX, Curini M, Marcotullio MC. 2015. Chemical composition and biological activities of fragrant Mexican copal (Bursera spp.). Molecules 20: 22383-22394.

Haryadi, Sunarto, Sugiyarto. 2019. Vegetation analysis of the secondary forest area in cangkringan resort, mount merapi national park. Jurnal Biodjati 4 (1): 50-57. [Indonesian]

Hutauruk TR, Hanjie AM, Simorangkir BDAS, Aipassa MI, Ruslim Y. 2018. The prospect of utilization of non-timber forest products from Setulang Village forest based on local knowledge of the Uma Lough Community in Malinau, North Kalimantan, Indonesia. Biodiversitas 19: 421-430.

Jacobson MG, Shiba PK. 2012. NTFP income contribution to household economy and related socio-economic factors: Lessons from Bangladesh. For Pol Econ 14: 136-142. DOI: 10.1016/j. forpol.20108.003. 
Jamal J. 2019. Analysis of ignition delay and burning rate of dammar resin. IOP Conf Ser Mater Sci Eng 619: 012037. DOI: 10.1088/1757899X/619/1/012037

Kubo H, Supriyanto B. 2010. From fence-and-fine to participatory conservation: mechanisms of transformation in conservation governance at the Gunung Halimun-Salak National Park, Indonesia. Biodiv Conserv 19 (6): 1785-1803.

Lee SM, Kim YS, Jaung W, Latifah S, Afifi M, Fisher LA. 2015. Forests, fuelwood and livelihoods-energy transition patterns in eastern Indonesia. Energ Pol 85: 61-70.

Lestari ND, Suprayogo D, Rachmansyah A. 2019. Local biodiversity conservation in Sigi, Central Sulawesi, Indonesia: Analysis of the effect of elevation land accessibility, and farmers' income and perception on vegetation diversity in agroforestry systems. Biodiversitas 20 (1): 283-291.

Lukmandaru G. 2017. Chemical components and anti-oxidative properties of copal. J Trop Wood Sci Technol 15 (1): 38-47.

Maryudi A. 2012. Proverty alleviation efforts through a community forestry program in Java, Indonesia. J Sustain Dev 5 (2): 43-53. DOI: 10.5539/jsd.v5n2p43-53.

Melese SM. 2016. Importance of non-timber forest production in sustainable forest management and its implication on carbon storage and biodiversity conservation in case of Ethiopia. J Biodiv Endang $\mathrm{Sp}$ 4 (1): $1-8$

Morhlade DM, Fulzele Sv, Satturwan PM, Joshi SB. 2006 Physicochemical properties and characterization of gum. Indian $\mathrm{J}$ Pharmaceut Sci 8 (1): 53-58.

Mukul SA, Uddin MB, ManzoornRA, Fox J. 2010. Integrating livelihoods and conservation in protected areas understanding the role and stakeholder views on prospects for non-timber forest products. A Bangladesh Case Study. Intl J Sustain Dev World Energ 17: 180-188.

Murugesan K, Ravi Kumar G, Jain SH, Mohan S, Nair SG. 2011. Wood exudates: an overview on aromatic gums and resins. J Indian Acad Wood Sci 8 (2): 72-75.
Nakagoshi N, Suheri H, Amelgia R. 2014. Community aspects of forest ecosystems in the Gunung Gede Pangrango National Park UNESCO Biosphere Reserve, Indonesia. In: Nakagoshi N, Mabuhay JA (eds.). Designing Low Carbon Societies in Landscapes, Springer, Tokyo.

Nana EJ. Techamadu NA. 2014. Socio economic impacts of Protected areas on people living close to the Mount Cameron National Park. Park 20 (2): 129-137. DOI: 10.230/IUCN.CH.2014.Parks-20-2 EDN.

Negi VS, Maikhuri RK, Rawat LS. 2011. Non-timber forest products (NTFPs) available option for biodiversity conservation and livelihood enhancement in Central Himalaya. Biodivers Conserv 20: 545-559.

Rosleine D, Suzuki E, Sundawiati A, Septiana W, Ekawati D. 2014. The effect of land use history on natural forest rehabilitation at corridor area of Gunung Halimun Salak National Park, West Java Indonesia. Reinwardtia 14 (1): 85-99.

Setiawan B, Lahjie AM, Yusuf S, Ruslim Y. 2019. Assessing the feasibility of forest plantation of native species: A case Study of Agathis dammara and Eusideroxylon zwageri in Balikpapan, East Kalimantan, Indonesia. Biodiversitas 20 (9): 2453-2461.

Setyawan AD. 2009. Traditionally utilization of Selaginella field and literature review. Nusantara Biosci 1 (3)146-158.

Soerianegara I, Indrawan A. 2002. Ekosistem Hutan Indonesia. Laboratorium Ekologi Hutan. Fakultas Kehutanan. Institut Pertanian Bogor, Bogor. [Indonesian]

Soumya KV, Shackleton CM, Setty SR. 2019. Harvesting and local knowledges of a cultural non-timber forest product (NTFP): Gum resin from Boswellia serrata Roxb. In three protected areas of Wester Ghats, India. Forest 10: 907. DOI: 10.3390/f10100907

Suminar P. 2013. Bringing in bourdieu's theory of practice: understanding community-based damar agroforest management in Pesisir Krui, West Lampung District, Indonesia. Intl J Human Soc Sci 3 (6): 201-213.

Wiharto M, Mochtar F. 2012. Tree species diversity of various vegetation types at the alliance level in submontane forest of Mount Salak, Bogor, West Java. J Dev Sustain Agric 7: 55-64. 